UDK 35.077.3:366.542

https://doi.org/10.18485/union_pf_ccr.2021.ch6

Prof. dr Jelena Jerinić ${ }^{*}$

\title{
POSEBNOSTI UPRAVNOG POSTUPKA ZA ZAŠTITU KOLEKTIVNOG INTERESA POTROŠAČA
}

\begin{abstract}
Apstrakt: Nakon ukidanja mogućnosti za podnošenje kolektivnih tužbi za zaštitu prava potrošača u parničnom postupku, u srpsko pravo uvedena je zaštita kolektivnih interesa potrošača u upravnom postupku. Autorka analizira karakteristike tog posebnog upravnog postupka, naročito imajući u vidu osnovna načela i strukturu našeg upravnog postupka, onako kako su oni određeni Zakonom o opštem upravnom postupku (ZUP). Ona zaključuje da su odstupanja od pravila opšteg upravnog postupka velika, posebno u pogledu kruga učesnika u postupku, kao i određenih procesnih instituta koja naš opšti upravni postupak ne poznaje. $U$ tom smislu, postavlja se pitanje adekvatnosti supsidijarne primene pravila ZUP-a u ovom postupku. Posebno se pažnja posvećuje poređenju tog postupka i postupka inspekcijskog nadzora koje u skladu sa Zakonom o zaštiti potrošača takođe sprovode organi državne uprave. Iz ove analize proizlaze $i$ određeni zaključci u pogledu adekvatnosti, odnosno delotvornosti ovakve zaštite kolektivnog interesa potrošača, imajući u vidu ulogu uprave u zaštiti potrošača, kao i određenje i ciljeve kolektivne zaštite, na način na koji su oni definisani u okviru evropskog pravnog prostora. Slede i određeni predlozi za izmene važećeg zakona.
\end{abstract}

Ključne reči: zaštita potrošača, kolektivni interes, zaštita kolektivnog interesa, posebni upravni postupak, načela upravnog postupka, Ministarstvo, inspekcijski nadzor.

\section{UVOD}

\subsection{UOPŠTE O MEHANIZMIMA ZA OBEZBEĐENJE PRIMENE ZAKONA O ZAŠTITI POTROŠAČA}

Iako to nije prevashodni predmet ovog članka, na početku treba dati određene napomene u pogledu različitih oblika kojima se može obezbediti primena ${ }^{1}$

* Vanredna profesorka Pravnog fakulteta Univerziteta Union u Beogradu e-mail: jelena.jerinic@pravnifakultet.rs

Rad je napisan kao rezultat istraživanja na naučnom projektu Pravnog fakulteta Univerziteta Union u Beogradu - Zaštita kolektivnih interesa potrošača u srpskom i uporednom pravu.

1 Literatura na engleskom jeziku, koja je većinom konsultovana u istraživanju za ovaj članak, koristi termin enforcement koji se na srpskom katkad prevodi kao „izvršenje“ ili „sprovođenje“ (zakona), ali se u ovom kontekstu suštinski odnosi na različite načine na koje se obezbeđuje primena propisa, odnosno propisima utvrđenih obaveza u oblasti zaštite potrošača, i to pre svega obaveza trgovaca. Na sličan način, i u nekim izvorima iz oblasti potrošačkog prava, pravi se razlika između pojmova enforcement i implementation, koji se najbolje prevodi kao 
propisa o zaštiti potrošača, posmatrano iz ugla modela koji su uočeni pre svega u evropskim državama. U literaturi se uobičajeno razlikuju javnopravni i privatnopravni. ${ }^{2}$ Mehanizmi za zaštitu kolektivnih interesa potrošača, u principu, mogu biti i javnopravni i privatnopravni. Postoje i druge podele od kojih su neke više (npr. podela na sudske i vansudske mehanizme, u okviru koje je i podela na sudske i upravne $e^{3}$ ), a neke manje relevantne za ovu analizu (npr. na mehanizme koji deluju ex ante ili ex post ${ }^{4}$ ).

Vratimo se na prvu podelu. Često se u literaturi nabrajaju mehanizmi koji pripadaju jednoj ili drugoj grupi (kao i oni koji ostaju izvan te podele) bez ukazivanja na kriterijum podele, te se time i sama podela svede na vrstu organa koji zaštitu pružaju. Na primer, među javnopravne mehanizme zaštite svrstavaju se zaštita u upravnom postupku i sudska zaštita pred prekršajnim ili krivičnim sudovima, dok je privatnopravna zaštita ona koju pružaju sudovi u parničnom postupku i različiti oblici vansudskog rešavanja potrošačkih sporova. ${ }^{5}$ Suština ove podele je u izvoru inicijative za pokretanje mehanizama zaštite - da li potiče od organa javne vlasti, ${ }^{6}$ koji deluju imajući u vidu javni interes, ili od privatnopravnih subjekata - najčešće potrošača ili njihovih udruženja. U tom smislu, lako je zaštitu koju pruža uprava (recimo, u inspekcijskom postupku) svrstati u javnopravnu grupu, a zaštitu koja se ostvaruje u parnici u privatnopravnu - bilo da se radi o zaštiti individualnog ili kolektivnog interesa potrošača. Međutim, kada se u upravnom postupku ostvaruje zaštita kolektivnih interesa potrošača koju mogu da iniciraju sami potrošači, preko ovlašćenih udruženja, gde je mesto tom postupku?

Neki autori smatraju da linija koja deli upravnopravnu i sudsku zaštitu više nije toliko jasna ili stroga, imajući u vidu verovatno i određenu ulogu koju u nekim državama organi uprave ili drugi organi javne vlasti mogu imati u pokretanju sudskih postupaka. ${ }^{7}$ Autorka ovog teksta smatra da zaštita koju potrošači ostvaruju u upravnom postupku koji sprovode organi uprave, na način na koji

primena (vid. npr. Micklitz, H. W., Saumier, G. (eds.), 2018, Enforcement and Effectiveness of Consumer Law (Vol. 27), Amsterdam, Springer.

2 Za jednostavan prikaz ove klasifikacije vid. npr. Karanikić Mirić, M., Mehanizmi zaštite zakonom garantovanih prava potrošača, u: Lilić, S. (prir.), 2013, Perspektive implementacije evropskih standarda u pravni sistem Srbije - knjiga 3, Beograd, Pravni fakultet, str. 173.

3 Npr. Cafaggi, F., Micklitz, H. W., 2008. Administrative and judicial enforcement in consumer protection: the way forward, EUI Working Papers, Law 2008/29, pp. 5-6.

4 Npr. Taboroši je razlikovao javnopravnu zaštitu, koja se pruža po pravilima trgovačkog ili privrednog prava, koji deluju ex ante, od obligacionopravne koja, po pravilu, deluje ex post. Vid. Taboroši, S., 2001, O potrebi donošenja zakona o zaštiti potrošača, Pravo i privreda, 5-8, str. 490-501. O tome i Јованић, Т., 2013, Управноправна заштита потрошача, Анали Правної

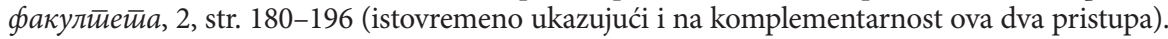

5 Tako npr. Jovanić, T., Uloga uprave u zaštiti kolektivnih interesa potrošača, u: Bourgoignie, T., Jovanić, T. (ur.), 2013, Strengthening Consumer Protection in Serbia - Jačanje zaštite potrošača u Srbiji, Liber Amicorum Svetislav Taboroši, Beograd, Pravni fakultet Univerziteta u Beogradu, str. 312.

6 Treba imati u vidu da je pojam „organi javne vlasti“ daleko širi od pojma „organi uprave“ i ovde se koristi da bi obuhvatio i sudove i organe državne uprave, kao i druge organe uprave i ostale specifične organe i tela koji mogu imati nadležnosti u ovoj oblasti. Vid. dalje u delu 1.2.

7 Npr. Jovanić, T., 2013, str. 312, ističući kao argument za to „akcesornu ulogu uprave u zaštiti kolektivnih interesa potrošača“. 
je to predviđeno važećim Zakonom o zaštiti potrošača, ${ }^{8}$ i dalje ostaje čvrsto na javnopravnoj strani, ${ }^{9}$ a argumenti za to dati su u narednim delovima teksta.

Pritom, ovo pitanje se ne postavlja isključivo u svrhu teorijske rasprave već je u službi analize adekvatnosti ovog rešenja kao mere javne politike. Može li se jedan mehanizam koji je po svojoj prirodi suštinski različit - i pripada privatnopravnoj strani zaštite potrošača - uspešno zameniti drugim, čija je svrha suštinski javnopravna?

$\mathrm{S}$ druge strane, u evropskoj literaturi se uglavnom govori o komplementarnosti raznih mehanizama, a njihovo poređenje vrši se na osnovu egzaktnih kriterijuma, na primer kroz uporedne studije koje mere delotvornost, ali i isplativost različitih mehanizama. ${ }^{10}$

\subsection{O ULOZI UPRAVE U ZAŠTITI POTROŠAČA}

Nesporna je uloga organa uprave (ili sličnih organa) u sistemu zaštite potrošača. Kada su u pitanju klasični organi uprave i upravni poslovi, to se svakako ostvaruje u oblasti nadzora, a specifično kroz inspekcijske poslove uprave. Sve veću ulogu u evropskim državama u ovoj oblasti imaju i tzv. regulatorna tela ili agencije koji katkad mogu imati i kvazisudska ovlašćenja. Iako ih sve možemo obuhvatiti pojmom javnopravnih mehanizama zaštite, potrebno je među njima napraviti i određena razgraničenja, posebno ako domaći sistem zaštite želimo da posmatramo iz uporednopravnog konteksta.

U literaturi o zaštiti prava potrošača na engleskom jeziku, a i na našem jeziku, ponekad se (gotovo) kao sinonimi koriste termini javno (engl. public) i upravno (engl. administrative), da bi se označili razni mehanizmi ili postupci koje preduzimaju organi ili tela koji pripadaju ili su u tesnoj vezi sa upravnom (administrativnom) strukturom jedne zemlje. Da bi se argumenti u ovom tekstu pravilno izveli, treba dati neka pojašnjenja u kontekstu važećeg srpskog prava.

8 Sl. glasnik RS, br. 62/14, 6/16 (dr. zakon), 44/18 (dr. zakon) (u daljem tekstu: ZZP 2014).

9 To primećuje і Јованић, Т., 2013, str. 183, prepoznajući da „propisi iz kruga javnog poretka“ nemaju kao cilj zaštitu subjektivnih prava potrošača, već zaštitu javnog poretka.

10 O komplementarnosti, odnosno „miksu“ različitih mehanizama, npr. Cafaggi \& Micklitz, 2008, p. 5, a na to ukazuje i Karanikić Mirić, M., 2013, str. 185. Vid. studiju koja izvodi cost-benefit analizu pet različitih modela obezbeđenja primene propisa o zaštiti potrošača (engl. models of enforcement), uključujući i merenje nivoa potencijalnog odvraćanja (engl. deterrence) poslovnih subjekata od kršenja propisa - Ogus, A. I., Faure, M. G., Philipsen, N. J., 2006, Best Practices for Consumer Policy: Report on the Effectiveness of Enforcement Regimes. Report prepared for the UK Department of Trade and Industry and OECD. DSTI/CP, London. Poređenje između američkih i evropskih modela zaštite pokazuje da u državama Evropske unije postoji veći stepen javnog regulisanja zaštite potrošača, a da je kolektivna zaštita pred sudom uglavnom zasnovana na inicijativi organa javne vlasti (i to agencija za zaštitu potrošača i potrošačkih ombudsmana) ili privatnopravnih organizacija potrošača, u: Cafaggi, F., Micklitz, H. W., 2008, p. 2. Takođe, konstatuje se da kada se državama članicama ostavi izbor, one češće biraju sudske od upravnih mehanizama, iako i to zavisi od konkretnog pitanja, pa $\mathrm{u}$ slučaju nepravičnih ugovornih obaveza preovlađuje privatnopravna, a kod nepravedne trgovačke prakse taj odnos je više uravnotežen. Za poređenje u okviru EU, vid. npr. Nessel, S., 2019, Consumer Policy in 28 EU Member States: An Empirical Assessment in Four Dimensions, Journal of Consumer Policy, 4, pp. 455-482. 
U našim propisima pojam „uprava” koristi se da bi se označila uprava u užem smislu, odnosno organi koji obavljaju upravne poslove, na tri različita nivoa vlasti - državna uprava, pokrajinska uprava i uprava jedinica lokalne samouprave. U kontekstu ZZP 2014, to je pre svega ministarstvo, kao organ državne uprave (u skladu sa Zakonom o državnoj upravi ${ }^{11}$ ). Pored ovih organa, neki poslovi koji su po svojoj prirodi upravni mogu biti povereni drugim organizacijama (npr. javnim službama, javnim agencijama i drugim) koje ih vrše kao javna ovlašćenja, te ih nazivamo imaocima javnih ovlašćenja. ${ }^{12} \mathrm{U}$ širem smislu, možemo i ove organe obuhvatiti pojmom javne uprave, ali treba imati u vidu da oni nisu organi državne uprave i da su po ulozi i ovlašćenjima posve različiti od ministarstava.

Zbog toga ne treba stavljati znak jednakosti između postupka koji (u našem ili nekom drugom pravnom sistemu) sprovodi ministarstvo, što se jedino sa sigurnošću može nazvati upravnom zaštitom prava potrošača u kontekstu važećih srpskih propisa, i onog koji u drugoj zemlji sprovodi javna agencija ili neko drugo telo (npr. ombudsman za zaštitu potrošača ili drugo specijalizovano nezavisno telo) koji su javnopravni i vansudski mehanizmi zaštite. Pored terminologije, ovo razlikovanje značajno je i zbog različitih ovlašćenja koja ova tela imaju u kontekstu konkretnog pravnog sistema.

Iako evropske države pripadaju srodnim upravnopravnim tradicijama, i uprava (u širem smislu) u njima obavlja slične poslove i ima slična ovlašćenja, ${ }^{13}$ u poređenju konkretnih nadležnosti u odgovarajućim oblastima treba poći od sistemskih propisa o organizaciji i delatnosti uprave u svakoj zemlji. Tako, u literaturi o zaštiti prava potrošača, uočavamo da organi uprave (i njima slični organi) mogu imati različita ovlašćenja - kako po vrsti tako i po intenzitetu tih ovlašćenja, ali prilikom poređenja sa rešenjima iz ZZP 2014 treba imati u vidu naše sistemske propise o upravi, prevashodno ZDU i Zakon o opštem upravnom postupku. ${ }^{14}$

$\mathrm{U}$ organizacionom smislu, u evropskim državama poslove $\mathrm{u}$ vezi sa zaštitom prava potrošača, u širem krugu organa javne uprave, obavljaju različiti organi i tela. Iako se u literaturi ova tela često označavaju terminom agencija (npr. na engleskom consumer agency ili public agency), u suštini, ona mogu imati različite oblike - mogu biti deo uprave (npr. ministarstva ili sektori unutar ministarstava), mogu biti nezavisna regulatorna tela (regulatorne agencije ili tela drugog naziva) ili specifična tela (kakvi su npr. ombudsmani za zaštitu potrošača). Specijalizovane agencije mogu biti isključivo nadležne za zaštitu potrošača, a mogu biti i deo organa ili tela sa širom nadležnošću (npr. trgovinom ili zaštitom konkurencije), isto kao što u nekim državama postoji više agencija koje su zadužene za zaštitu

11 Sl. glasnik RS, br. 79/05, 101/07, 95/10, 99/14, 30/18 - dr. zakon, 47/18 (u daljem tekstu: ZDU).

12 Vid. npr. Милосављевић, Б., 2019, Уӣравно йраво - Сеgмо изменено и gойуюено изgаюе, Београд, Правни факултет Универзитета Унион и Службени гласник, str. 44-45. O pojmovima javne i državne uprave, vid. npr. Јеринић, J., 2016, Запошљавање у јавном сектору у Србији - допринос дефинисању основних појмова и анализи правног оквира, Аяминистирација и јавне йолитиике, 3, str. 7-27.

13 Npr. Seerden, R. (ed.), 2012, Administrative Law of the European Union, Its Member States and the United States, Third Edition, Cambridge, Intersentia.

14 Sl. glasnik RS, br. 18/16, 95/18 - autentično tumačenje (u daljem tekstu: ZUP). 
potrošača u različitim oblastima. Stvari se dodatno komplikuju u državama sa složenim državnim uređenjem, u kojima ova tela mogu postojati na različitim nivoima vlasti. Sektorske agencije zadužene su npr. za tržište telekomunikacija, finansijskih usluga i bankarstva, energetike, vodosnabdevanja, saobraćaja, bezbednosti hrane ili farmaceutskih proizvoda, u nekim zemljama postojale su i pre uspostavljanja agencija za zaštitu potrošača opšte nadležnosti, dok su u drugim obrazovane naknadno, za oblasti u kojima se za to pojavila posebna potreba. Sektorske agencije čak ponekad uživaju veću samostalnost i imaju šira nadzorna i izvršna ovlašćenja, uključujući i neka kvazisudska ovlašćenja kakvo je izricanje sankcija. Kako će ova tela izgledati zavisi od mnogo faktora, među kojima je i upravna tradicija u određenoj zemlji. Evropeizacija u tom pogledu je izostala, a propisi EU ne sadrže zahteve u vezi s tim i ne očekuju harmonizaciju u pogledu organizacionih oblika. ${ }^{15}$ Štaviše, nije primećena direktna veza između izbora institucionalnog modela i veće ili manje efikasnosti zaštite prava potrošača u datim državama. ${ }^{16}$

Primer sektorske agencije nalazimo u hrvatskom HAKOM-u (Hrvatska regulatorna agencija za mrežne djelatnosti) koji ima nadležnosti u pogledu zaštite potrošača. ${ }^{17} \mathrm{Za}$ zemlje regiona, u literaturi se mogu naći argumenti za uspostavljanje specijalizovanih agencija za zaštitu potrošača. ${ }^{18}$

U Srbiji, ZZP 2014 kao nosioce zaštite potrošača identifikuje: Narodnu skupštinu, Vladu, Ministarstvo [nadležno za zaštitu potrošača] i druga ministarstva, Nacionalni savet za zaštitu potrošača, regulatorna tela koja imaju zakonom utvrđene nadležnosti u oblasti zaštite potrošača, organe autonomne pokrajine i lokalne samouprave, udruženja i saveze. ${ }^{19}$ Među svim ovim akterima, upravne poslove u vezi sa obezbeđenjem poštovanja propisa o zaštiti potrošača imaju odgovarajuća ministarstva i organi uprave teritorijalnih jedinica - u sferi nad-

15 S druge strane, postoje propisi EU koji predviđaju potrebna ovlašćenja regulatornih tela. $\mathrm{Na}$ primer, tzv. CPC Uredbom (o saradnji u oblasti zaštite potrošača), među potrebnim ovlašćenjima nadležnih organa, navode mogućnost izricanja privremenih mera, prijema obaveštenja od prodavaca o preduzetim merama i mogućnost izricanja kazni. Regulation (EU) 2017/2394 of the European Parliament and of the Council of 12 December 2017 on cooperation between national authorities responsible for the enforcement of consumer protection laws and repealing Regulation (EC) No 2006/2004. O tome npr. Hodges, C., 2018, Collective Redress: The Need for New Technologies, Journal of Consumer Policy, Vol. 42, No. 1, pp. 65-66. Takođe, postoje direktive u ovoj oblasti koje sadrže detaljnija pravila u vezi sa postupcima za zaštitu potrošačkih prava. O tome Karanikić Mirić, M., 2013, str. 173.

16 Cafaggi, F., Micklitz, H. W., 2008, pp. 20-21; Micklitz, H. W., Saumier, G., 2018, pp. 11-13; Rott, P. W., Effective enforcement of consumer law: the comeback of public law and criminal law, in: Devenney, J., Kenny, M. (eds.), 2012, European Consumer Protection: Theory and Practice, Cambridge University Press, p. 64.

17 Micklitz, H. W., Saumier, G., 2018, p. 219.

18 Hrvatski autori iznosili su ideje o specijalizovanoj regulatornoj agenciji za zaštitu potrošača (npr. Baretić, M., Zaštita potrošača u Republici Hrvatskoj nakon ulaska u Europsku uniju jesmo li implementacijom europskog prava izgradili sustav zaštite potrošača? u: Bourgoignie, T., Jovanić, T. (ur.), 2013, str. 99; a slični predlozi dati su i za druge zemlje u regionu (vid. npr. Lončar Velkova, M., Dabović Anastasovska, J., Nepoštena poslovna praksa: Iskustva EU u primeni Direktive 2005/29/EC, u: Bourgoignie, T., Jovanić, T. (ur.), 2013, str. 166). 
zora, a posebno inspekcijskog nadzora, kao i u posebnom postupku za zaštitu kolektivnog interesa potrošača. Ostali akteri uglavnom imaju uloge u definisanju i sprovođenju strategije za zaštitu potrošača. Zanimljivo je da ZZP ovde ne ubraja sudove, iako uređuje potrošačke sporove, kao ni tela za vansudsko rešavanje potrošačkih sporova.

U našem pravnom sistemu, regulatorna tela nisu česta. ${ }^{20} \mathrm{Ne}$ treba ih mešati sa širim pojmom agencija. Većina agencija kod nas ima status javnih agencija, u skladu sa Zakonom o javnim agencijama, ${ }^{21}$ i nema karakter regulatornih tela. Ne postoji krovni zakon o regulatornim telima, niti zakon koji sadrži definiciju njihovog pojma, a određenom telu karakter „regulatornog“ ili „nezavisnog regulatornog" daje zakon kojim je ono osnovano. ${ }^{22}$

Iako ih prepoznaje kao „nosioce zaštite potrošača“, ZZP 2014 ne daje ovim telima ulogu u postupku zaštite kolektivnih prava - niti kao nadležnim organima, niti kao podnosiocima zahteva. ${ }^{23}$

Takođe, iako može delovati kao notorna činjenica, naši organi državne uprave (npr. ministarstva) nemaju regulatornu funkciju, na način na koji je imaju regulatorna tela ili regulatorne agencije. ${ }^{24} \mathrm{Ne}$ treba posebno navoditi ni da nisu nezavisni.

Konačno, u literaturi se često pominju i specijalizovani ombudsmani za zaštitu potrošača, uglavnom u skandinavskim zemljama (npr. Finska, Danska), ali i u drugim državama Evrope. Ova specijalizovana tela uglavnom su vezana za glavnu regulatornu agenciju, odnosno nadležno ministarstvo, u smislu izve-

20 O regulatornim agencijama u zemljama u regionu vid. npr. Koprić, I., Kovač, P., Musa, A., 2012. Agencies in three South Eastern European countries: Politics, expertise and law, NISPAcee Journal of Public Administration and Policy, 2, pp. 17-44, a o propisima u Srbiji npr. Radojević, M., 2010, Nezavisna (regulatorna) tela i institucije u Srbiji, Sprska politička misao, 4, str. 53-76.

21 Sl. glasnik $R S$, br. 8/05, 81/05 - ispravka, 47/18.

22 Na primer, Agencija za energetiku Republike Srbije osnovana je Zakonom o energetici (Sl. glasnik RS, br. 145/14, 95/18 - dr. zakon) kao regulatorno telo (član 38. stav 1) koje je „samostalni pravni subjekt i nezavisna od organa izvršne vlasti“ (stav 2). Regulatorna agencija za elektronske komunikacije i poštanske usluge (RATEL), osnovana Zakonom o elektronskim komunikacijama (Sl. glasnik RS, br. 44/10, 60/13 - US, 62/14, 95/18 - dr. zakon), određena je kao „nezavisna regulatorna organizacija” (član 7). Komisija za zaštitu konkurencije, prema Zakonu o zaštiti konkurencije (Sl. glasnik RS, br. 51/09, 95/13) je „samostalna i nezavisna organizacija koja vrši javna ovlašćenja" (član 20), a Regulatorno telo za elektronske medije (REM), prema Zakonu o elektronskim medijima (Sl. glasnik RS, 83/14, 6/16 - dr. zakon) predstavlja „samostalnu nezavisnu regulatornu organizaciju sa svojstvom pravnog lica, koja vrši javna ovlašćenja" (član 5).

23 Neiskorišćenost potencijala domaćih „sektorskih regulatora“ prepoznaje і Јованић, Т., 2013, str. 188. Slično i Fejös, A., 2013, The impact of EU norms and policies on consumer protection enforcement in Serbia, Journal of Consumer Policy, pp. 265-266, koja govori posebno o potencijalnoj ulozi Komisije za zaštitu konkurencije u sudskim postupcima za zaštitu kolektivnih interesa potrošača (tekst je pisan u vreme važenja ranijeg zakona - Zakon o zaštiti potrošača, Sl. glasnik RS, br. 73/10, u daljem tekstu: ZZP 2010).

24 Ipak, postoje autori koji ovu funkciju pominju u kontekstu upravnopravne zaštite kolektivnog interesa potrošača. Vid. npr. Бабовић, Б., 2014, Заштита колективних интереса потрошача, Анали Правноі факулиетейа у Беоїраgy, 2, str. 222. 
štavanja i nadzora, ali u nekim zemljama mogu donositi obavezujuće odluke, dok u drugim primaju pritužbe na osnovu kojih postupaju u cilju pronalaženja sporazumnog rešenja (npr. grčki potrošački ombudsman), te se označavaju kao mehanizmi za alternativno rešavanje sporova. ${ }^{25}$ Takođe, ova tela često su legitimisana da iniciraju parnične potrošačke sporove, odnosno upućuju predloge za vođenje krivičnog postupka. ${ }^{26}$ Iako nose takav naziv, treba primetiti da to nisu ombudsmani u smislu našeg Zaštitnika građana, koji je nezavisni državni organ koji štiti prava građana i kontroliše upravu, i naš pravni sistem ih ne poznaje.

Imajući u vidu navedene organizacione nijanse, kada se u cilju analiziranja stanja u pravu Srbije predstavljaju rešenja iz drugih zemalja, potrebna je opreznost. Između različitih oblika koje nalazimo u uporednim analizama i onih koji postoje u domaćim propisima ne treba stavljati znak jednakosti, jer mnogi od ovih prvih koji imaju važna ovlašćenja u vezi sa zaštitom prava potrošača u našoj zemlji ne postoje ili nemaju takva ovlašćenja. ${ }^{27}$

U uporednopravnim pregledima primećuje se da ovi organi kada imaju nadležnosti u zaštiti potrošača mogu imati nadzorna i izvršna ovlašćenja, dok drugi imaju samo nadzorna, a izricanje sankcija je rezervisano za sudske organe. ${ }^{28}$ Ministarstva su, kao i naša, uobičajeno ovlašćena za sprovođenje nadzora nad primenom zakona, što neizostavno uključuje inspekcijski nadzor. Nadzor se može inicirati pritužbama potrošača ili drugih lica (uključujući i udruženja) ili po službenoj dužnosti - bilo nasumično ili na osnovu nekog definisanog modela za procenu rizika. ${ }^{29}$

Mere koje mogu da izriču organi uprave i specijalizovane agencije su različite. Oni retko mogu da izriču novčane kazne, a treba napomenuti da to ne mogu ni naši organi državne uprave. ${ }^{30}$ Mere koje podrazumevaju intervenciju $\mathrm{u}$ poslovanje trgovca (npr. suspenzija dozvole, privremeno obustavljanje delatnosti, naredba da se prestane sa nezakonitom praksom ili ukidanje nepravičnih ugovornih klauzula itd.) su češće, ali u nekim zemljama i za to je potrebna sud-

25 Vid. npr. Hodges, C., 2019, pp. 67-68.

26 Više u Micklitz, H. W., Saumier, G., 2018, pp. 15-16; Ogus, A. I., Faure, M. G., Philipsen, N. J., 2006, p. 14.

27 Tako npr. kod Jovanić, T., 2013, govori se o sprovođenju zaštite potrošača „od strane javnih agencija za zaštitu potrošača, odnosno organa uprave” ili ovlašćenjima ,javnopravne/upravnopravne zaštite", a prilikom izlaganja o superiornijem položaju organa uprave, u odnosu na oblike sudske zaštite, suštinski se govori o regulatornim telima (vid. posebno str. 312-313 i 325). Iako može biti jasno da se ovde misli na iskustva drugih zemalja, to nije dovoljno naglašeno.

28 Cafaggi, F., Micklitz, H. W., 2008, p. 5; Micklitz, H. W., Saumier, G., 2018, pp. 9-10.

29 Ogus, A. I., Faure, M. G., Philipsen, N. J., 2006, p. 15.

30 Organi uprave u upravnom postupku mogu izricati novčane kazne jedino kao mere procesne discipline (npr. član 115. ZUP) ili u postupku prinudnog izvršenja upravnih akata, kao meru posredne primene (član 198. ZUP). U postupku inspekcijskog nadzora, inspektor može jedino izdati prekršajni nalog (Zakon o inspekcijskom nadzoru, Sl. glasnik RS, br. 36/15, 44/18 - dr. zakon, 95/18, u daljem tekstu: ZIN), a Zakonom o prekršajima (Sl. glasnik RS, br. 65/13, 13/16, 98/16 - US, 91/19 - dr. zakon, 91/19, član 168) predviđeno je da se prekršajni nalog izdaje samo kada je za prekršaj zakonom ili drugim propisom od prekršajnih sankcija predviđena samo novčana kazna u fiksnom iznosu. 
ska odluka. U svakom slučaju, odluke ovih organa podležu sudskoj kontroli (u upravnom sporu ili sličnom postupku). ${ }^{31}$ Treba primetiti da mere obustavljanja nepravične poslovne prakse mogu izricati i klasični organi uprave, kakvi su inspektorati, u postupku inspekcijskog nadzora. ${ }^{32}$

Sa stanovišta ostvarivanja zaštite kolektivnog interesa potrošača, važna su ovlašćenja za pokretanje sudskih postupaka za zaštitu prava (koja češće imaju specijalizovane agencije za zaštitu potrošača i tela slična ombudsmanu nego klasični organi uprave). Dakle, ova tela ne odlučuju o zaštiti kolektivnog interesa, već su legitimisana da pokreću sudske postupke zaštite, a čak i kada nisu jedini legitimisani, de facto igraju presudnu ulogu. ${ }^{33}$ Primećeno je i da u ovim zemljama, udruženja za zaštitu potrošača zbog toga imaju manje značajnu ulogu u pokretanju ovih postupaka, koja se često svodi na podnošenje prijava ili predstavki ovim javnopravnim telima. ${ }^{34}$

Međutim, legitimacija javnopravnih tela za pokretanje sudskog postupka kolektivne zaštite retko uključuje obeštećenje pogođenih potrošača, već je cilj da se obezbedi sudska potvrda nepravedne poslovne prakse ili nepravičnih ugovornih uslova, odnosno da se takva praksa prekine. Doduše, u nekim slučajevima potrošači mogu te sudske odluke koristiti da ostvare naknadu štete u zasebnim parnicama. ${ }^{35}$

Imajući sve navedeno u vidu, pozivamo na opreznost prilikom kvalifikovanja određenih entiteta kao „upravnih“ jer, iako mogu biti deo upravnog aparata ili u određenoj vezi sa njim (imajući u vidu način njihovog osnivanja, finansiranja i sl.), oni suštinski nisu organi uprave, kakva su ministarstva u smislu našeg Zakona o državnoj upravi (a i propisa drugih zemalja).

31 Micklitz, H. W., Saumier, G., 2018, pp. 13-14. Npr. hrvatski HAKOM ovlašćen je da suspenduje ili izmeni opšte uslove poslovanja koji nisu u skladu sa zakonom o elektronskim komunikacijama, a može voditi i postupak u slučaju nepravedne poslovne prakse. Podaci iz ranijih godina pokazuju da se ovi postupci iniciraju mnogo češće nego sudski postupak za zaštitu kolektivnih interesa potrošača. Npr. u periodu od 2010. do 2014. vođen je samo jedan sudski postupak, u poređenju sa skoro 1300 predmeta pred HAKOM-om. (Ibid., str. 219).

32 Primer nalazimo u hrvatskom Zakonu o zaštiti potrošača. Vid. Micklitz, H. W., Saumier, G., 2018, p. 219.

33 Ibid., str. 6, 19; Nagy, C. I., European Models of Collective Actions u: Nagy, C. I. (ed.), 2019, Collective Actions in Europe - Comparative, Economic and Transsystemic Analysis, Cham, Springer Nature, p. 117. Takva je situacija, recimo u skandinavskim zemljama, u kojima potrošački ombudsmani podnose kolektivne tužbe za naknadu štete, kao i sa novijim članicama EU, u kojima su to uglavnom organizacione jedinice nadležnih ministarstava. U nekim državama, te sudske postupke pokreću i javni tužioci. O ovome, u kontekstu zaštite koju pružaju različita regulatorna tela (engl. regulatory redress), Hodges, C., 2019, pp. 63-68.

34 Ibid. U tom pogledu je u literaturi istican britanski OFT (Office of Fair Trading) koji je bio dužan da navode iz prigovora udruženja potrošača istraži u roku od 90 dana. Međutim, ovo telo ukinuto je, a njegove nadležnosti preuzelo je više drugih organa. Vid. https://www.gov. uk/government/organisations/office-of-fair-trading (12. 9. 2020). Slično, holandski ACM (Authority for Consumers and Markets) i AFM (Authority for Financial Markets) primaju pritužbe potrošača koje mogu biti osnov za njihove istrage ili samo za nadzor nad funkcionisanjem tržišta (Ibid., p. 401).

35 Micklitz, H. W., Saumier, G. (eds.), 2018, pp. 13-14. 


\subsection{ULOGA UPRAVE U ZAŠTITI PRAVA POTROŠAČA U SRBIJI}

U domaćoj literaturi nema mnogo izvora koji se bave isključivo ulogom uprave u zaštiti potrošača, odnosno posebnom upravnopravnom zaštitom u skladu sa ZZP 2014. ${ }^{36}$ Međutim, u nekim od tih izvora postoje određene generalizacije u vezi sa pojmom uprave, poslovima uprave, pa i upravnim postupkom i pojmom upravne stvari koje, onda, utiču i na shvatanje posebne upravnopravne zaštite kolektivnih interesa potrošača. To je delimično uslovljeno i proučavanjem uloge uprave u ovoj oblasti u drugim zemljama, gde postoji drugačiji institucionalni kontekst, o čemu je već bilo reči u delu 1.2. ovog teksta, posebno u kontekstu specijalizovanih i regulatornih tela za zaštitu potrošača i ombudsmana za zaštitu potrošača. Uloga uprave u zaštiti potrošača, što uključuje i posebni postupak zaštite kolektivnog interesa potrošača pred organima uprave, mora se $u$ našem kontekstu posmatrati u okvirima važećih propisa o organizaciji uprave i njenim ovlašćenjima, odnosno opštih propisa o upravnom postupku.

Kao što je već rečeno, ZZP 2014 organe uprave (ministarstva kao organe državne uprave i organe uprave teritorijalnih jedinica) svrstava među nosioce zaštite potrošača. ZZP 2014 predviđa poslove ministarstva nadležnog za zaštitu potrošača u članu 126. (među kojima se pored upravnih poslova - vođenja upravnog postupka i vršenja upravnog nadzora - nalaze i brojni drugi poslovi koji se u teoriji upravnog prava često nazivaju kreativno-političkim poslovima ${ }^{37}$ ), a određene poslove stavlja i u delokrug drugih ministarstava, kao i organa uprave autonomne pokrajine i jedinica lokalne samouprave (u članu 154). ${ }^{38}$

U grupu upravnih poslova koji su prevashodni predmet ovog teksta ulaze: sprovođenje postupka i određivanje mera zaštite kolektivnog interesa potrošača; podnošenje zahteva za pokretanje prekršajnog postupka zbog povrede kolektivnog interesa potrošača; upravljanje i vršenje nadzora nad Nacionalnim registrom potrošačkih prigovora; kao i vršenje nadzora nad primenom ZZP 2014, što uključuje inspekcijski nadzor.

Nadzor nad primenom ZZP 2014, u skladu sa članom 154, vrši ministarstvo nadležno za zaštitu potrošača, kao i drugi državni organi i organi teritori-

36 Upravnopravnoj zaštiti posvećeni su npr. tekstovi: Јованић, Т., 2013; Бабовић, Б., 2014, str. 215-228; Karanikić Mirić, M., 2014, Kolektivna zaštita potrošača u srpskom pravu, Anali Pravnog fakulteta Univerziteta u Zenici, 7, str. 57-83, a kratak osvrt daje i Jovanović Zattila, M., 2014, Anali Pravnog fakulteta Univerziteta u Zenici, 1, str. 33-55. Za analizu odredaba ranijeg ZZP iz 2010. godine, između ostalog, i u vezi sa ulogom uprave, v. Karanikić Mirić, M., 2013.

37 O ovoj vrsti poslova uprave vid. Милосављевић, Б., 2019, str. 222-224. Među dvadeset poslova navedenih u članu 124. ZZP 2014, većina su takvi poslovi (npr. kreiranje politike zaštite potrošača i praćenje njenog sprovođenja kroz druge državne politike; saradnja i koordiniranje sa drugim nosiocima zaštite potrošača; unapređenje pravnog okvira i usklađivanje sa propisima EU; podržavanje rada i razvoja udruženja i saveza; promocija istraživanja i naučnih projekata u oblasti zaštite potrošača; podsticanje donošenja kodeksa dobre poslovne prakse). Može se primetiti da u ovom članu nije navedeno vođenje evidencije udruženja i saveza za zaštitu potrošača, iako je taj posao ministarstva uređen u čl. 132-134. ZZP 2014.

38 Pored toga, nekoliko ministarstava daje svoje predstavnike u Nacionalni savet za zaštitu potrošača (član 127). 
jalnih jedinica, u okviru svog delokruga. Inspekcijski nadzor vrše tržišni inspektori i turistički inspektori. Iako je, barem u trenutnoj organizaciji, reč o istom ministarstvu, ${ }^{39}$ treba imati u vidu ovu podelu prilikom analize odredaba o zaštiti kolektivnog interesa potrošača i inspekcijskom nadzoru.

Kao što ispravno primećuju i drugi autori, i drugi zakoni koji uređuju posebne oblasti pružanja usluga (npr. energetika, turizam, finansijske usluge, telekomunikacije, bezbednost hrane itd.) predviđaju nadležnosti organa uprave, ali i drugih državnih organa (npr. Narodne banke, Agencije za energetiku, RATEL-a itd.) koje možemo posmatrati u kontekstu zaštite potrošača. ${ }^{40}$ Barem u smislu Narodne banke, jer je o ograničenoj ulozi regulatornih agancija već napomenuto, ipak se mora reći da upravnopravna zaštita kod nas nije jedini oblik vansudske javnopravne zaštite, te se tako između ove dve kategorije ne može stavljati znak jednakosti.

Dalji tekst odnosi se na analizu odredaba ZZP 2014 o posebnom upravnom postupku zaštite kolektivnog interesa potrošača (a u vezi sa tim delimično i odredbama istog zakona o inspekcijskom nadzoru) koji sprovodi nadležno ministarstvo.

\section{UPRAVNI POSTUPAK ZA ZAŠTITU KOLEKTIVNOG INTERESA POTROŠAČA}

Upravni postupak o kome je reč uveden je u naš pravni poredak Zakonom o zaštiti potrošača iz 2014. godine. Pre toga, bila je predviđena zaštita kolektivnog interesa potrošača u parničnom postupku, odnosno kao oblik privatnopravne sudske zaštite. To je rešenje izostavljeno iz novog zakona (ZZP 2014), nakon odluke Ustavnog suda kojim su stavljene van snage odredbe Zakona o parničnom postupku iz 2011. godine ${ }^{41}$ o posebnom parničnom postupku za zaštitu kolektivnih prava i interesa. ${ }^{42} \mathrm{U}$ suštini, Ustavni sud je našao da te odredbe nisu ispunile standard kvaliteta normi, jer su bile „nejasne i neprecizne, što objektivno ugrožava ostvarivanje prava na pravnu sigurnost i jednaku zaštitu prava pred sudovima". 43

Odlukom Ustavnog suda kojom su stavljene van snage odredbe ZPP-a koje su omogućavale sudsku zaštitu kolektivnog interesa potrošača, zakonodavac je praktično primoran da kolektivnu zaštitu obezbedi na drugi način, te je „utočišste" pronašao u upravnom postupku. $\mathrm{U}$ ovom tekstu, analiziraju se odredbe ZZP

39 Prema članu 8. Zakona o ministarstvima (Sl. glasnik RS, br. 44/14, 14/15, 54/15, 96/15 - dr. zakon, 62/17) svi ovi poslovi su u nadležnosti Ministarstva trgovine, turizma i telekomunikacija.

40 Npr. Karanikić Mirić, M., 2013, str. 189, primećuje takve nadležnosti Narodne banke (naravno, u vezi sa pružanjem finansijskih usluga), kao i nadležnih inspekcija u skladu sa Zakonom o opštoj bezbednosti proizvoda (Sl. glasnik RS, br. 41/09, 77/19).

41 Sl. glasnik RS, br. 72/11, 49/13 - US, 74/13 - US, 55/14, 87/18, 18/20 (u daljem tekstu: ZPP).

42 Odluka Ustavnog suda broj IУ3-51/2012 od 23. maja 2013. godine.

43 Za osvrt na ovu odluku vid. npr. Karanikić Mirić, M., 2013, str. 177-181, a za njenu kritiku npr. Bodiroga, N., 2013, Komentar odluke Ustavnog suda IUz-51/2012 o neustavnosti Glave 36 Zakona o parničnom postupku, Pravni instruktor, 45. 
2014 upravo iz tog ugla, odnosno ispituje se stepen posebnosti tog upravnog postupka, čime bi se barem delom moglo doći i do zaključaka o adekvatnosti upravnog postupka za ispunjenje zadatka kolektivne zaštite potrošača, imajući u vidu, između ostalog, i zakonska rešenja drugih zemalja.

Iako je u literaturi ova odluka Ustavnog suda predstavljena kao prevashodni cilj drugačijeg rešenja u pogledu zaštite kolektivnog interesa, ${ }^{44}$ zakonodavac je ovu promenu između ostalog obrazložio potrebom da se ojača „državni institucionalni okvir politike zaštite potrošača“ $i$ to „preciziranjem nadležnosti Ministarstva“. Takođe, istaknuto je da odredbe ZZP 2010 koje su uređivale vansudsko rešavanje potrošačkih sporova „ne pokrivaju u dovoljnoj meri ovu oblast i neophodno ih je uskladiti sa novim odredbama Zakona o parničnom postupku ('Službeni glasnik RS', br. 72/11, 49/13-US, 74/13-US i 55/14) koji uređuje postupak u potrošačkim sporovima". Takođe, uvođenje upravnog postupka za zaštitu kolektivnog interesa potrošača, prema zakonodavcu znači da se ostvaruje „efektivnija zaštita“ ... jer je „upravni postupak [...] brži i efikasniji od sudskog““ 45

Apstraktno posmatrano, brzina, odnosno efikasnost upravnog postupka u odnosu na sudske postupke teško se može osporavati, kao ni njegova ekonomičnost koju zakonodavac nije naveo kao posebnu prednost za potrošače, ali se ona redovno ističe u literaturi. Međutim, ako govorimo o efektivnosti, odnosno delotvornosti, merenje se može izvesti samo na osnovu procene efekata ovih postupaka, što znači da je zakonodavac morao da pokaže da su efekti upravnog postupka (po prava potrošača) isti ili bolji nego efekti sudske zaštite ovih prava. ${ }^{46}$

Donekle sličan razvoj situacije u pogledu zaštite kolektivnog interesa potrošača nalazimo u Hrvatskoj, u kojoj je od 2003. godine ona bila u nadležnosti sudova, a izmenama zakona iz 2007. prebačena na organe uprave, odnosno nadležni inspektorat, a zatim 2009. ponovo vraćena sudovima. U Hrvatskoj su, međutim, u međuvremenu razvijeni još neki mehanizmi za pojedine oblasti pružanja usluga - pred regulatornim telima (npr. pomenutim HAKOM-om u oblasti telekomunikacija) ili posebnim inspektoratima. ${ }^{47}$

44 Mada u literaturi nalazimo i navođenja drugih potencijalnih razloga. Npr. kod Бабовић, Б., 2014, str. 221-222, nagađa se da su to mogli biti i „društveno okruženje, nedovoljna razvijenost aktivnosti udruženja potrošača [iako se i u ovom postupku predviđa važna uloga udruženja, prim. aut.] i nepostojanje odgovarajućih mehanizama za olakšavanje prethodnog snošenja troškova, što bi potencijalno moglo dovesti do zlouptreba“. Takođe, komentatori ZZP 2010 istakli su brojne njegove mane koje su takođe mogle da budu razlog za izmene. Npr. u Karanikić Mirić, M., 2013, str. 170-174, kao razlozi neefikasne zaštite prava vide se u nedostacima procesnih odredaba ZZP 2010, kao i u činjenici da je ovaj zakon istovremeno smanjio ovlašćenja nadležnih inspekcija i propustio da propiše odgovarajuća pravila o sudskim postupcima zaštite.

45 Obrazloženje Predloga zakona o zaštiti potrošača preuzeto je iz pretplatničkog dela elektronske baze Službenog glasnika - Mišljenja, modeli i literatura, (https://www.pravno-informacioni-sistem.rs/mml-standard-search, 1. 9. 2020).

46 U literaturi se kao argument veće efikasnosti organa uprave dovode u vezu sa tvrdnjom da je „nadležna inspekcija ili regulator ekspert u datoj oblasti, što obezbeđuje odgovorniji pristup zaštiti kolektivnih interesa“. Vid. Јованић, T., 2013, str. 186.

Vid. npr. Micklitz, H. W., Saumier, G., 2018, p. 225. 
Zaštita kolektivnog interesa potrošača uređena je u glavi XIV ZZP 2014 (čl. 145-153). U ovim članovima ZZP 2014 je: definisao pojam kolektivnog interesa (član 145); odredio nadležnost za vođenje postupka, način pokretanja postupka i odredio ovaj postupak kao posebni upravni postupak (član 146); utvrdio legitimaciju za podnošenje zahteva za pokretanje postupka (član 147); utvrdio svojstvo stranaka u postupku i odredio da se postupak pokreće zaključkom (član 148); odredio karakter odluke kojom se okončava postupak, predvideo izjašnjenje lica protiv koga se vodi postupak i tzv. korektivnu izjavu, i utvrdio konačnost rešenja donetih u ovom postupku (član 149); nabrojao mere zaštite kolektivnog interesa (član 150); uredio privremenu meru (član 151); zatim prekid postupka (član 152) i, na kraju, utvrdio kakav je uticaj ovog postupka na ostvarivanje individualnog prava na naknadu štete (član 153).

Nadzor nad primenom ZZP 2014 uređen je u njegovoj glavi XV, što uključuje inspekcijski nadzor. Odredbama čl. 154-159. uređena su ovlašćenja inspektora u vršenju nadzora, uz koja se primenjuju i opšta pravila Zakona o inspekcijskom nadzoru, kao i pravila Zakona o opštem upravnom postupku.

\subsection{KARAKTER POSTUPKA}

U članu 146. stav 5. ZZP 2014 predviđeno je da se u postupku zaštite kolektivnog interesa primenjuju pravila opšteg upravnog postupka, osim ako njime nije drugačije propisano. Šta ovo u suštini znači i zbog čega je to važno?

U našem pravnom sistemu, a nema razloga ne reći da je to slučaj i u mnogim drugim, na veliki broj odnosa primenjuju se pravila upravnog postupka. Kod nas, to se čini tako što se zakonima upućuje na primenu ili na shodnu prime$n u$ pravila opšteg upravnog postupka, odnosno ZUP-a.

Ova sitna terminološka razlika nije sitna u pogledu pravnih posledica. $U$ prvom slučaju, pravila ZUP-a primenjuju se direktno i supsidijarno, kao lex specialis, i tada kažemo da se radi o posebnom upravnom postupku, ${ }^{48}$ a u drugom se primenjuju shodno, odnosno prilagođeno prirodi konkretnog postupka.

Kada je nekim zakonom predviđeno da se ZUP na njega primenjuje shodno, to znači da se na neki odnos (npr. na pravnu zaštitu izbornog prava) pravila opšteg upravnog postupka ne primenjuju u potpunosti, već u meri u kojoj postoji sličnost, odnosno u meri u kojoj to odgovara cilju i pravnoj prirodi tog odnosa. Zato kažemo da se tada ZUP primenjuje po sličnosti ili po analogiji. ${ }^{49}$ Ovakvi postupci nisu posebni upravni postupci, odnosno nisu upravni postup-

48 Vid. npr. Лончар, 3., 2016, Посебни уйравни йостиуйци, Зборник раgова Правної факул-

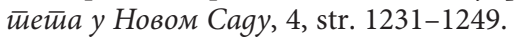

49 Radi se o uobičajenom metodu popunjavanja pravnih praznina. O tome npr. Лукић, Р. Д., 1994, Увоg у йраво, Београд, Службени лист СРЈ, str. 323-327; Васић, Р., Јовановић, М., Дајовић, Г., 2019, Увоg у ирраво, Београд, Правни факултет Универзитета у Београду, str. 368-371; Спасојевић, Ж., Аналогија и тумачење (избор), и: Баста, Д., 1991, Преображаји ugeje иррава, Београд, Правни факултет Универзитета у Београду, str. 113-129.

O shodnoj primeni pravila opšteg upravnog postupka vid. npr. Pljakić, Lj., 2016, Upravno postupanje u novom Zakonu o opštem upravnom postupku, Pravni život, 10, str. 247. 
ci uopšte, a u upravnopravnoj teoriji oni se negde nazivaju i „postupcima posebne vrste". 50

$S$ druge strane, kada zakon prosto kaže da se na odnose koje on uređuje pravila ZUP-a primenjuju (kao u članu 146. ZZP 2014), onda se radi o supsidijarnoj i neposrednoj primeni, odnosno radi se o posebnom upravnom postupku, a pravila ZUP-a primenjuju se uvek kada posebnim zakonom nije ništa predviđeno. Dakle, ako želi da isključi primenu neke odredbe ZUP-a, zakonodavac to mora i da napiše.

Naš pravni poredak obiluje posebnim upravnim postupcima, ${ }^{51}$ a verovatno nije mali broj ni onih kod kojih se ZUP primenjuje shodno. Postupak zaštite kolektivnog interesa potrošača je, dakle, posebni upravni postupak, a ne sui generis postupak na koga se pravila upravnog postupka (samo) shodno primenjuju.

Sam ZUP predviđa meru dozvoljenih odstupanja od svojih pravila - „pojedina pitanja upravnog postupka mogu posebnim zakonom da se urede samo ako je to u pojedinim upravnim oblastima neophodno, ako je to u saglasnosti sa osnovnim načelima određenim ovim zakonom [prim. aut. ZUP-om] i ne smanjuje nivo zaštite prava i pravnih interesa stranaka zajemčenih ovim zakonom [ZUP-om]. ${ }^{\text {52 }}$ Drugi zahtev koji se odnosi na nivo zaštite interesa stranaka tumači se tako da obuhvata celinu odredaba ZUP-a, pre svega onih o procesnim ovlašćenjima stranke. ${ }^{53}$

Dalja analiza odredaba ZZP 2014 pokazuje da u njemu odstupanja od pravila opšteg upravnog postupka nisu mala, ali da postoje i otvorena pitanja o nameri zakonodavca da se na neke segmente postupka zaštite kolektivnog interesa potrošača primenjuju odredbe ZUP-a.

\subsection{ODSTUPANJA OD PRAVILA OPŠTEG UPRAVNOG POSTUPKA}

\subsubsection{Pokretanje postupka i učesnici u postupku}

ZZP 2014 sadrži nekoliko odredaba o pokretanju postupka i učesnicima u postupku koje u određenoj meri nisu usklađene sa važećim ZUP-om. Međutim, prilikom analize tih odredaba treba imati u vidu da je ZZP 2014 usvojen za vreme važenja ranijeg ZUP-a koji je na drugačiji način uređivao neke segmente postupka, među kojima i pokretanje upravnog postupka.

50 Tako Димитријевић, П., 2014, Нека отворена питања примене ЗУП-а, Зборник раgова Правноі фокулиетей у Нишу, 68, str. 149-150.

51 Prilikom donošenja važećeg ZUP-a, zakonodavac je, napravivši sličnu procenu, postavio rok za usklađivanje svih posebnih zakona koji predviđaju primenu ZUP-a. Rok za to je istekao u junu 2018. godine. Vladi je naloženo da za te potrebe obrazuje posebno koordinaciono telo. Vid. član 214. ZUP-a. U okviru te aktivnosti, izrađen je popis zakona koje treba uskladiti sa ZUP-om, a koji uređuju barem po jedan postupak u kome se ZUP supsidijarno primenjuje ukupno 265 u 12 oblasti. Vid. http://mduls.gov.rs/obavestenja/utvrdjena-matrica-za-usaglasavanje-posebnih-zakona-sa-zakonom-o-opstem-upravnom-postupku/?script=lat (14. 9. 2020).

52 Član 3. stav 2. ZUP.

53 Tako Томић, 3., 2017, Коментиар Закона о ойшием уйравном йосииуйку, са суgском йраксом и реїистиром йојмова, Београд, Службени гласник, str. 106. 
ZZP 2014 kaže da postupak pokreće nadležno ministarstvo, po zahtevu ovlašćenog lica ili po službenoj dužnosti. ZUP predviđa da se upravni postupak pokreće zahtevom stranke ili po službenoj dužnosti (član 90). Dakle, kada stranka podnese zahtev na koji je zakonom ovlašćena, postupak je pokrenut i nema potrebe da ga organ formalno pokreće, npr. donošenjem nekog posebnog akta o pokretanju postupka. Naravno, organ može doneti akt o pokretanju postupka (npr. zaključak, pa je u tom smislu član 148. stav 3. ZZP 2014), a obavezan je da to učini pre pokretanja postupka po službenoj dužnosti koji nije u interesu stranke (vid. član 90. stav 3. ZUP).

Naravno, nadležni organ vodi postupak, odnosno njime upravlja. ${ }^{54}$ Međutim, to ne znači da organ može odlučiti da postupak ne pokrene, već bi, u slučaju da smatra da nisu ispunjeni uslovi za vođenje postupka (pre svega oni navedeni u članu 145. ZZP 2014) morao da donese rešenje o odbacivanju (vid. član 90. ZUP) ili, ako utvrdi da ne postoji povreda zakona od strane trgovca, rešenje o odbijanju zahteva protiv koga se mogu uložiti odgovarajuća pravna sredstva, odnosno, u ovom slučaju, pokrenuti upravni spor.

Imajući u vidu navedenu obavezu usklađivanja posebnih zakona sa ZUPom, odredbe ZZP 2014 o pokretanju postupka morale bi da budu usklađene sa novim ZUP-om. ${ }^{55}$

Obavezni učesnici svakog upravnog postupka jesu nadležni organ i, najčešće, jedna stranka, ali je moguće da postoji i više stranaka. Najčešće se u postupcima koji se pokreću po službenoj dužnosti stranci utvrđuje neka obaveza, dok se u postupcima koji se pokreću zahtevom stranke radi o priznavanju nekog prava stranci, mada je moguće da prava budu utvrđivana i u postupcima koji se vode ex officio.

Nije često, ali nije ni nemoguće da postupak može da se pokrene ili zahtevom stranke ili po službenoj dužnosti. Nije, dalje, neuobičajeno ni da u upravnom postupku bude više stranaka. ${ }^{56}$ Međutim, ono što jeste neuobičajeno jeste da se istovremeno u jednom postupku jednoj stranci priznaje neko pravo, a da se drugoj utvrđuje neka obaveza.

Kada se postupak vodi (po službenoj dužnosti) da bi se stranci utvrdila neka obaveza, to se čini jer je to u javnom interesu, odnosno predviđeno je zakonom ili drugim propisom. Zbog toga se u tim slučajevima ne kaže da se upravni postupak vodi protiv te stranke. Taj izraz ne koristi se čak ni u slučaju inspekcijskog nadzora, iako ovaj postupak može, imajući u vidu da se u njemu utvrđuje posto-

54 I u literaturi je primećeno da je jedna od ključnih razlika između upravnih i sudskih mehanizama zaštite potrošača u tome što je kod upravnih, iako postoje procesna ovlašćenja drugih učesnika u postupku, glavnina odgovornosti za tok postupka na organu uprave i on dominantno utiče na njegov tok. Vid. npr. Cafaggi, F., Micklitz, H. W., 2018, p. 5.

55 Međutim, u tekstu Nacrta zakona o zaštiti potrošača koji je objavljen 1. 11. 2019. godine na veb-prezentaciji nadležnog ministarstva, iako su formulacije u ovim odredbama donekle izmenjene (vid. član 172. Nacrta), njihovo značenje je i dalje isto i nije u potpunosti usklađeno sa ZUP-om. Vid. https://mtt.gov.rs/slider/javne-rasprava-o-nacrtu-ozp/ (15. 9. 2020).

56 Tada se govori o višestranačkoj upravnoj stvari i o tzv. kolidirajućim strankama. Vid. Милосављевић, Б., 2019, str. 285-286. ZUP koristi termin „protivna stranka“. 
janje nezakonitosti, imati kao posledicu izricanje mera za njihovo otklanjanje, pa i neke sankcije.

U tome je i suština određenja upravne stvari, koja se određuje kao, po pravilu, nesporna životna situacija u kojoj je neophodno da organi uprave donesu autoritativno rešenje kojim se nekome priznaje neko pravo ili utvrđuju obaveze. Definicija upravne stvari, odnosno činjenica da li se radi o spornoj ili nespornoj situaciji, u našoj pravnoj teoriji nije predmet o kome postoji potpuni konsenzus. ${ }^{57} \mathrm{U}$ krajnjoj liniji, već je rečeno da postoje tzv. višestranačke upravne stvari u kojima više stranaka ima suprotstavljene interese, te se može reći da među njima postoji nekakav spor. U tom smislu, i u situaciji koju uređuje ZZP 2014, spor postoji između potrošača i trgovca i to na način na koji je to definisano njegovim članom 140, koji se doduše odnosi samo na sudski postupak.

Međutim, ono što jeste jasno to je da spor nije u odnosu između nadležnog organa i stranke, čak i ako ta stranka krši zakon, odnosno cilj njihovog učešća u postupku nije rešavanje spora koji među njima postoji, već obezbeđenje javnog interesa koji se, u konkretnom slučaju, sastoji u poštovanju zakona, odnosno garantovanih prava potrošača. Nisu poreska administracija i poreski obveznik u sporu, bez obzira na to koliko ovaj drugi ne želi da plati porez. Isto tako, tržišna (ili druga) inspekcija koja nadzire poštovanje prava potrošača nije u sporu sa trgovcem ili prodavcem, već je ovlašćena da nadzire primenu zakona u ovoj oblasti.

Ovo dodatno potvrđuje da se radi o postupku koji se vodi u javnom interesu, a ne u individualnom, pa čak ni kolektivnom, kako god on bio shvaćen. ${ }^{58} \mathrm{Mi}$ nistarstvo pokreće postupak zbog toga što trgovac krši zakon, a to bi u svakom slučaju učinilo i u okviru svojih nadzornih ovlašćenja.

Govoreći o vođenju postupka protiv, ZZP 2014 implicira da se radi o postupku koji po svojoj prirodi nije upravni, jer je reč o terminologiji koja je svoj-

57 Principijelno nesporni ili vansporni karakter kao važan element upravne stvari predstavlja npr. Томић, 3., 2017, str. 86-91 ili Tomić, Z., 2010, Komentar Zakona o upravnim sporovima sa sudskom praksom, Službeni glasnik, str. 290 (u kome daje i primere koji ukazuju da je takav i preovlađujući stav sudske prakse). Nešto drugačije Lilić, S., 2019, Zakon o opštem upravnom postupku - Anatomija zakonskog projekta sa modelom za generalnu rekonstrukciju ZUP-a, Beograd, Centar za unapređenje zakonodavstva, Komitet pravnika za ljudska prava, str. 73-78. Upravnu stvar, čak, na donekle različit način određuju ZUP i Zakon o upravnim sporovima (Sl. glasnik RS, br. 111/2019, u daljem tekstu: ZUS). Član 5. ZUS-a određuje upravnu stvar (u smislu tog zakona) kao „pojedinačnu nespornu situaciju od javnog interesa u kojoj neposredno iz pravnih propisa proizilazi potreba da se buduće ponašanje stranke autoritativno pravno odredi." (kurziv naš) Član 2. ZUP-a upravnu stvar (u smislu tog zakona) određuje nešto šire kao „pojedinačnu situaciju u kojoj organ, neposredno primenjujući zakone, druge propise i opšte akte, pravno ili faktički utiče na položaj stranke tako što donosi upravne akte, donosi garantne akte, zaključuje upravne ugovore, preduzima upravne radnje i pruža javne usluge“. Pored toga, dopušta i da se kao upravna stvar odredi i „svaka druga situacija koja je zakonom određena kao upravna stvar“.

58 Zbog njegovog usmerenja na pitanja upravnog postupka, u ovom tekstu nije detaljnije analiziran pojam kolektivnog interesa, niti pojam kolektivnog interesa potrošača, ali treba reći da u teoriji postoje otvorena pitanja i dileme u vezi sa tim. Vid. npr. Micklitz, H. W., Saumier, G., 2018, p. 4 (koji postavljaju pitanje o granicama između individualnog i kolektivnog, odnosno kolektivnog i javnog interesa) ili Karanikić Mirić, M., 2013, str. 170 (o pojmu kolektivnog interesa potrošača kao jedne „razuđene, nehomogene grupe“). 
stvena sudskim postupcima (npr. tužba se podnosi protiv, krivična prijava se podnosi protiv itd.). Iako razlog može biti u činjenici da se u suštini radi o sudskom postupku koji je „prebačen“ u delokrug uprave, ako je već tako, možda bi bilo opravdano razmišljati o određenju ovog postupka kao posebnog, sui generis postupka, na koji se ZUP primenjuje shodno.

Dalje, ZZP 2014 kao legitimisane za pokretanje postupka poznaje samo evidentirana udruženja (član 147), a svojstvo stranaka priznaje samo podnosiocu zahteva i licu protiv koga se vodi postupak. S druge strane, krug legitimisanih aktivnih stranaka shvata mnogo šire i određuje da stranka može biti i svako lice na čija prava, obaveze ili pravne interese može da utiče ishod toka postupka (vid. član 44. stav 1. ZUP), a posebno predviđa da tzv. zastupnici kolektivnih interesa i zastupnici širih interesa javnosti organizovani saglasno propisima mogu imati svojstvo stranke (član 44. stav 3. ZUP), te omogućava da se podnese zahtev za priznanje svojstva stranke (član 93. ZUP). Tekst člana 147. ZZP 2014 ne ukazuje da to ne bi bilo moguće.

Takođe, već je rečeno da regulatorna tela koja imaju nadležnosti koje su u bliskoj vezi sa zaštitom potrošača nemaju posebnu ulogu u ovom postupku. Oni se tretiraju na isti način kao podnosioci inicijative ili davaoci informacija, odnosno nemaju svojstvo stranke u postupku (član 148. stav 2). Na taj način oni se suštinski stavljaju u položaj podnosioca predstavke u postupku inspekcijskog nadzora (član 18. stav 3. ZIN), a može se reći i da su, iako državni organi, u nepovoljnijem položaju od evidentiranih udruženja potrošača.

Gotovo identično rešenje nalazimo u Zakonu o zaštiti konkurencije (član 33), ${ }^{59}$ a o neravnopravnosti uporedivih subjekata u postupku pred Komisijom za zaštitu konkurencije već je pisano. ${ }^{60}$

Konačno, pogledajmo koje su pravne posledice priznavanja svojstva stranke podnosiocima zahteva, odnosno udruženjima. Imajući u vidu odredbe ZUP-a, udruženjima u ovom postupku pripadaju sve procesne garancije stranke u pogledu aktivnog učešća u postupku, izvođenja dokaza i sl., ali je glavna razlika, koja suštinski razdvaja ovaj postupak od postupka inspekcijskog nadzora, u činjenici da udruženje nezadovoljno rešenjem Ministarstva može da protiv tog rešenja koristi odgovarajuća pravna sredstva.

\subsubsection{Tok $i$ ishod postupka}

Uređujući odluke koje nadležno ministarstvo može doneti u ovom postupku, ZZP 2014 takođe odstupa od pravila ZUP-a, ali se istovremeno približava odredbama ZIN-a.

Kada utvrdi da postoji povreda, te da je potrebno odrediti neku od mera iz člana 150, Ministarstvo će doneti rešenje (član 149. stav 1) koje je konačno u upravnom postupku, odnosno protiv njega se jedino može pokrenuti upravni spor (stav 5), što ZUP dozvoljava (vid. član 151. stav 1). To rešenje se objavljuje

59 Sl. glasnik RS, br. 51/09, 95/13.

60 Npr. Томић, 3., 2017, str. 289-291. 
na internet stranici Ministarstva (član 150. stav 3), što je viši standard od onog koji zahteva ZUP, a verovatno je uslovljeno važnošću interesa koji se u ovom postupku štite.

Nije posebno predviđeno, ali će Ministarstvo, u skladu sa odredbama ZUP-a, rešenjem odlučiti i ako utvrdi da povreda nema, kao i u pomenutom slučaju kada proceni da zahtev treba odbaciti (recimo, kao nedozvoljen ili izjavljen od strane neovlašćenog lica).

U istom članu, između ovih stavova, ZZP 2014 govori o obaveštenju koje se upućuje licu protiv koga je pokrenut postupak i kojim se ono poziva na izjašnjenje (u roku od 15 dana koji, imajući u vidu rokove za donošenje rešenja iz ZUP-a nije zanemarljiv). U tom izjašnjenju, ovo lice može dati tzv. korektivnu izjavu predlog obaveza koje je spremno da preduzme radi otklanjanja povrede zakona. Iz odredaba člana 152. o prekidu postupka, može se zaključiti da se sve ovo čini pre donošenja rešenja.

Korektivna izjava nije institut koji poznaje ZUP, ali to nije neuobičajeno, a ni zabranjeno. ${ }^{61}$ Ovaj institut, međutim, podseća na mere za otklanjanje nezakonitosti, iz člana 27. ZIN-a, s tim što se umesto obaveštenja, u inspekcijskom nadzoru stranci dostavlja zapisnik, i ne ostavlja joj se sloboda kako da nezakonitosti ispravi.

Član 151. ZZP 2014 predviđa mogućnost određivanja privremene mere (doduše, pominje samo da to čini na predlog podnosioca zahteva). To je u skladu sa ZUP-om, s tim što bi trebalo imati u vidu da je u tom slučaju potrebno da se o privremenoj meri, bez odlaganja, donese privremeno rešenje (vid. član 105. stav 2. ZUP).

Konačno, treba reći da ZUP prekid postupka pominje samo u vezi sa rešavanjem prethodnog pitanja, dok ga ZZP 2014 predviđa u vezi sa korektivnom izjavom, ali se ne može reći da je to u suprotnosti sa pravilima opšteg upravnog postupka.

Konačno, mere iz člana 150. ZZP 2014, iako različite od onih koje može izreći nadležni inspektor (član 156. istog zakona), veoma su im slične zbog same činjenice da se i u jednom i u drugom slučaju izriču zbog uočenih nepravilnosti, odnosno nezakonitosti. U tom smislu, mogla bi se braniti i hipoteza da bi nadležnost za vođenje postupka zaštite kolektivnog interesa potrošača mogla da ima i inspekcija.

Prirodno, ove mere uže su od posledica koje može imati privatnopravna, sudska zaštita kolektivnog interesa (to se pre svega tiče mogućnosti za odlučivanje o naknadi štete i izricanju kazni). Imajući to u vidu, ako utvrdi da je došlo do povrede kolektivnog interesa potrošača, ministarstvo podnosi zahtev za pokretanje prekršajnog postupka nadležnom organu, za prekršaje predviđene ZZP 2014 (vid. član 150. stav 4).

61 O tome npr. Томић, 3., 2017, str. 107-108, koji navodi primere iz carinskog postupka i postupaka eksproprijacije i zaštite patenata. 


\subsubsection{Petogodišnja praksa}

Kratko vreme primene odredaba ZZP 2010 o sudskoj zaštiti kolektivnog interesa donelo je samo jedan takav postupak, kako o tome izveštavaju objavljeni radovi iz ove oblasti. ${ }^{62} \mathrm{Za}$ kraj ove kratke analize, na osnovu podataka nadležnog ministarstva sačinjen je prikaz podnetih zahteva i objavljenih rešenja kojima su u skladu sa ZZP 2014 izrečene odgovarajuće mere u periodu od 2015. do 2019. godine. ${ }^{63}$ Autorka nije pronašla objavljene podatke o pokrenutim upravnim sporovima protiv rešenja ministarstva u istom periodu.

\begin{tabular}{|c|c|c|c|c|}
\hline \multirow{2}{*}{ Godina } & \multirow{2}{*}{ Podneti zahtevi } & \multicolumn{3}{|c|}{ Objavljena rešenja o merama } \\
\hline & & $\begin{array}{l}\text { Ukupno } \\
\text { rešenja }\end{array}$ & $\begin{array}{l}\text { U postupcima } \\
\text { po zahtevu }\end{array}$ & $\begin{array}{l}\text { U postupcima po } \\
\text { službenoj dužnosti }\end{array}$ \\
\hline 2019. & $\begin{array}{l}17 \text { zahteva / } \\
1 \text { odbačen }\end{array}$ & 1 & 1 & - \\
\hline 2018. & 31 zahtev & 3 & 1 & 2 \\
\hline 2017. & $\begin{array}{l}19 \text { zahteva / } \\
1 \text { povučen }\end{array}$ & 3 & 2 & 1 \\
\hline 2016. & $\begin{array}{l}16 \text { zahteva / } \\
1 \text { neosnovan }\end{array}$ & 8 & 5 & 3 \\
\hline 2015. & $\begin{array}{l}\text { Izveštaj nije } \\
\text { dostupan }\end{array}$ & 1 & 1 & - \\
\hline $\begin{array}{l}\text { Ukupno } \\
(2015-2019)\end{array}$ & $\begin{array}{l}83^{*} \text { (bez podatka } \\
\text { za } 2015)\end{array}$ & 16 & 10 & 6 \\
\hline
\end{tabular}

Osim 2016. godine, kada je donet najveći broj rešenja kojima su utvrđene mere, u ostalim godinama taj broj je veoma mali. Treba uzeti u obzir da je broj podnetih zahteva u svakoj od godina bio daleko veći od broja onih na čijem kraju su izrečene mere. Iako o tome postoje neke informacije u godišnjim izveštajima (npr. da su neki postupci obustavljeni jer je trgovac ispravio nepravilnosti i sl.), nije moguće analizirati ostale postupke, odnosno razloge za njihov drugačiji ishod, jer se odluke donete u tim postupcima ne objavljuju.

62 Npr. Bodiroga, N., 2013 o kolektivnoj tužbi udruženja korisnika finansijskih usluga protiv tri banke.

63 Podaci o donetim rešenjima preuzeta su iz popisa objavljenih rešenja sa veb-prezentacije Ministarstva trgovine, turizma i telekomunikacija, (https://mtt.gov.rs/informacije/zastita-potrosaca/resenje-o-povredi-kolektivnog-interesa-potrosaca/, 14. 9. 2020). S obzirom na zakonsku obavezu objavljivanja tih rešenja, pretpostavka je da se u tom popisu i nalaze sva rešenja doneta u periodu 2015-2019. Za 2020. godinu nema objavljenih rešenja. Podaci o podnetim zahtevima preuzeti su iz objavljenih godišnjih izveštaja o radu Nacionalnog registra potrošačkih prigovora, (https://mtt.gov.rs/informacije/zastita-potrosaca/, 15. 9. 2020). 


\section{ZAKLJUČCI}

Iako analiza efekata različitih mehanizama zaštite interesa potrošača nije bila predmet ovog teksta (a to bi potpuno prevazišlo ograničena znanja autorke u oblasti potrošačkog prava), autorka u potpunosti staje uz stav izražen u dostupnoj literaturi da pluralizam mehanizama zaštite treba posmatrati kao prednost, čak i ne uzimajući u obzir specifičnosti pravnog, društvenog, kulturnog i svakog drugog okvira u kome ti mehanizmi funkcionišu.

U tom smislu, zaštita potrošača treba da se ostvaruje i pred organima uprave i pred drugim organima sličnim upravi, kao i pred sudovima i u okviru drugih privatnopravnih mehanizama - i to kako zaštita njihovog individualnog, tako i kolektivnog interesa. Međutim, posedujući znanja pre svega iz oblasti upravnog prava, autorka upozorava na opasnosti „transplantacije“ bilo kog postupka iz jednog u drugi mehanizam - u ovom slučaju iz sudskog u upravni, kao i nekritičkog korišćenja iskustava drugih zemalja u dizajniranju mera javne politike u srpskim uslovima. U tom smislu se u ovom tekstu i insistira na jasnom definisanju položaja nadležnog organa, odnosno razgraničenju različitih organa i tela koja se mogu svrstati pod širi pojam ,javne uprave“. Zaključak koji se iz tog dela može izvući jeste da poslovi koji se stavljaju u delokrug organa državne uprave moraju biti u skladu sa njihovom prirodom, u protivnom se ne mogu očekivati rezultati koje ti organi inače ostvaruju u drugim oblastima.

Dalje, poredeći procesna pravila sadržana u važećem Zakonu o zaštiti potrošača, autorka zaključuje da je, birajući da ovaj postupak odredi kao posebni upravni postupak, zakonodavac morao da uzme u obzir celinu odredaba Zakona o opštem upravnom postupku, odnosno da neke njegove odredbe izričito isključi ako nije imao nameru da se one primenjuju (ako je takvo isključenje u skladu sa odredbama ZUP-a i moguće). To se prevashodno odnosi na odredbe o pokretanju postupka i na odredbe o svojstvu stranaka u postupku zaštite kolektivnog interesa potrošača. Izneti argumenti govore i u prilog potrebe da se odredbe ZZP 2014 usklade sa odredbama važećeg ZUP-a koji je donet nakon toga.

$S$ druge strane, ako se proceni da je ovaj postupak previše specifičan i različit u odnosu na opšti upravni postupak (i ostale posebne upravne postupke), ništa ne sprečava zakonodavca da predvidi shodnu primenu pravila ZUP-a.

Posmatrajući tok postupka zaštite kolektivnog interesa potrošača, autorka smatra da je ovaj postupak po svojoj suštini veoma sličan postupku inspekcijskog nadzora. To se, na primer, odnosi na karakteristike pasivne stranke (kojoj se utvrđuje obaveza, odnosno izriče mera), neke procesne institute i, konačno, karakter mera koje se izriču. U tom smislu, a u cilju pojednostavljenja institucionalne raspodele uloga, može se razmisliti i o poveravanju vođenja ovog postupka inspekcijskim organima. To ne bi bilo neuobičajeno, imajući u vidu iskustva drugih evropskih zemalja.

Konačno, a vraćajući se na početni argument o komplementarnosti raznorodnih mehanizama zaštite, mere koje organi uprave mogu da izreknu, pa samim tim i efekti na prava potrošača i njihov kolektivni interes, i dalje nisu takvi 
da mogu u potpunosti nadomestiti zaštitu pred sudom. Dakle, iako kao korisna i, verovatno brža i jeftinija varijanta, treba da bude zadržana u našem pravnom poretku, upravnopravna zaštita kolektivnog interesa potrošača ne treba da bude posmatrana kao zamena za sudsku, a upravni postupak kao neka vrsta "postupka opšte prakse“. Sa sličnom argumentacijom, autorka, kao i neki drugi pre nje, ukazuje na nedovoljnu uključenost drugih organa javne vlasti (pre svega, postojećih regulatornih agencija) u ostvarivanje mehanizama zaštite kolektivnog interesa potrošača u Srbiji.

\section{LITERATURA}

1. Бабовић, Б., 2014, Заштита колективних интереса потрошача, Анали Правноі

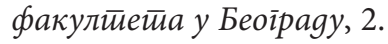

2. Baretić, M., Zaštita potrošača u Republici Hrvatskoj nakon ulaska u Europsku uniju - jesmo li implementacijom europskog prava izgradili sustav zaštite potrošača? u: Bourgoignie, T., Jovanić, T. (ur.), 2013, Strengthening Consumer Protection in Serbia Jačanje zaštite potrošača u Srbiji, Liber Amicorum Svetislav Taboroši, Beograd, Pravni fakultet Univerziteta u Beogradu.

3. Bodiroga, N., 2013, Komentar odluke Ustavnog suda IUz-51/2012 o neustavnosti Glave 36 Zakona o parničnom postupku", Pravni instruktor, 45.

4. Васић, Р., Јовановић, М., Дајовић Г., 2019, Увоg у йраво, Београд, Правни факултет Универзитета у Београду.

5. Cafaggi, F., Micklitz, H. W., 2008, Administrative and judicial enforcement in consumer protection: the way forward, EUI Working Papers, Law 2008/29.

6. Devenney, J., Kenny, M. (eds.), 2012, European consumer protection: theory and practice, Cambridge, Cambridge University Press.

7. Димитријевић, П., 2014, Нека отворена питања примене ЗУП-а, Зборник раgова Правной факулиетейа у Нищу, 68.

8. Fejös, A., 2013, The impact of EU norms and policies on consumer protection enforcement in Serbia, Journal of Consumer Policy, 3.

9. Hodges, C., 2018, Collective Redress: The Need for New Technologies, Journal of Consumer Policy, 1.

10. Јеринић, J., 2016, Запошљавање у јавном сектору у Србији - допринос дефинисању основних појмова и анализи правног оквира, Аgминисиращија и јавне йолийике, 3.

11. Jovanić, T., Uloga uprave u zaštiti kolektivnih interesa potrošača, u: Bourgoignie, T., Jovanić, T. (ur.), 2013, Strengthening Consumer Protection in Serbia - Jačanje zaštite potrošača u Srbiji, Liber Amicorum Svetislav Taboroši, Beograd, Pravni fakultet Univerziteta u Beogradu.

12. Јованић, Т., 2013, Управноправна заштита потрошача, Анали Правної факуліиейа Универзииести у Беоїраgу, 2.

13. Jovanović Zattila, M., 2014, Anali Pravnog fakulteta Univerziteta u Zenici, 1.

14. Karanikić Mirić, M., Mehanizmi zaštite zakonom garantovanih prava potrošača, u: Lilić, S. (prir.), 2013, Perspektive implementacije evropskih standarda u pravni sistem Srbije - knjiga 3, Beograd, Pravni fakultet Univerziteta u Beogradu. 
15. Karanikić Mirić, M., 2014, Kolektivna zaštita potrošača u srpskom pravu, Anali Pravnog fakulteta Univerziteta u Zenici, 7.

16. Koprić, I., Kovač, P., Musa, A., 2012, Agencies in three South Eastern European countries: Politics, expertise and law. NISPAcee Journal of Public Administration and Policy, 2.

17. Lilić, S., 2019, Zakon o opštem upravnom postupku - Anatomija zakonskog projekta sa modelom za generalnu rekonstrukciju ZUP-a, Beograd, Centar za unapređenje zakonodavstva, Komitet pravnika za ljudska prava.

18. Лончар, 3., 2016, Посебни уйравни йостиуйци, Зборник раяова Правної факулйе$\bar{u}$ а у Новом Сagy, 4.

19. Lončar Velkova, M., Dabović Anastasovska, J., Nepoštena poslovna praksa: Iskustva EU u primeni Direktive 2005/29/EC, u: Bourgoignie, T., Jovanić, T. (ur.), Strengthening Consumer Protection in Serbia - Jačanje zaštite potrošača u Srbiji, Liber Amicorum Svetislav Taboroši, Beograd, Pravni fakultet Univerziteta u Beogradu.

20. Лукић, Р. Д., 1994, Увоg у йраво, Београд, Службени лист СРЈ.

21. Micklitz, H. W., Saumier, G. (eds.), 2018, Enforcement and Effectiveness of Consumer Law (Vol. 27), Amsterdam, Springer.

22. Милосављевић, Б., 2019, Уӣравно ирраво - Сеgмо измеюено и gойуюено изgаюе, Београд, Правни факултет Универзитета Унион и Службени гласник.

23. Nagy, C. I. (ed.), 2019, Collective Actions in Europe - A Comparative, Economic and Transsystemic Analysis, Cham, Springer Nature.

24. Nessel, S., 2019, Consumer Policy in 28 EU Member States: An Empirical Assessment in Four Dimensions, Journal of Consumer Policy, 4.

25. Ogus, A. I., Faure, M. G., Philipsen, N. J., 2006, Best Practices for Consumer Policy: Report on the Effectiveness of Enforcement Regimes. Report prepared for the UK Department of Trade and Industry and OECD. DSTI/CP, London, (http://www.oecd. org/dataoecd/56/7/37863861.doc).

26. Pljakić, Lj., 2016, Upravno postupanje u novom Zakonu o opštem upravnom postup$\mathrm{ku}$, Pravni život, 10.

27. Radojević, M., 2010, Nezavisna (regulatorna) tela i institucije u Srbiji, Sprska politička misao, 4.

28. Rott, P. W., Effective enforcement of consumer law: the comeback of public law and criminal law, u: Devenney, J., Kenny, M. (eds.), 2012, European Consumer Protection: Theory and Practice, Cambridge University Press.

29. Seerden, R. (ed.), 2012, Administrative Law of the European Union, Its Member States and the United States, Third Edition, Cambridge, Intersentia.

30. Спасојевић, Ж., Аналогија и тумачење (избор), u: Баста, Д., 1991, Преображаји ugeje ирава, Београд, Правни факултет Универзитета у Београду.

31. Taboroši, S., 2001, O potrebi donošenja zakona o zaštiti potrošača, Pravo i privreda, $5-8$.

32. Tomić, Z., 2010, Komentar Zakona o upravnim sporovima sa sudskom praksom, Službeni glasnik.

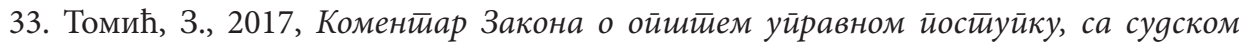
ирраксом и реїисииром йојмова, Београд, Службени гласник. 


\title{
SPECIFICITIES OF SERBIAN ADMINISTRATIVE PROCEDURE FOR PROTECTION OF CONSUMER'S COLLECTIVE INTEREST
}

\author{
Jelena Jerinić
}

\begin{abstract}
SUMMARY
Although this text did not deal with comparison of effects different mechanisms of enforcement of consumer protection, the author supports the position expressed in available literature on the advantages which a plurality of mechanisms can bring to a legal system, regardless of the specific legal, social, cultural and any other framework in which these mechanisms operate. After possibilities for collective redress of consumer interests before the courts, via a collective claim, were abolished, Serbian law turned to collective redress in an administrative procedure. The author analyses the features of the special administrative procedure, particularly bearing in mind the basic principles and structure of general administrative procedure, as provided by the Serbian Law on General Administrative Procedure (LGAP). In doing that, the author warns of dangers which "transplantation" of any procedure from one to another mechanism could bring - in this case, from a judicial to an administrative mechanism - as well as of uncritical use of experiences of other jurisdictions in designing policy measures in specific Serbian circumstances. In that sense, the text insists on the clear definition of ministries as competent bodies and their delineation from other bodies which can be classified with the wider category of public administration. Tasks put before ministries have to be in line with their nature and position within the Serbian legal system or otherwise the results these bodies normally achieve in other areas cannot be expected. The author concludes that the departures form rules of LGAP are sizable, especially in relation to the circle of parties to the procedure, as well as introduction of institutes unfamiliar to Serbian general administrative procedure. Particular attention is awarded to comparison of this procedure with the procedure of inspection oversight, which according to the Serbian Law on Consumer Protection is also carried out by public administration bodies, i.e. line ministries. This analysis also lead to some conclusions on the suitability and effectiveness of such collective redress, bearing in mind the role of the administration in enforcement of consumer protection and the definition and aims of collective redress, as understood within the European legal space. This is followed by several proposals for amendments to the existing law. Hence, although a useful and probably faster and a less expensive option, administrative enforcement should maintain in the Serbian legal system, but should not be viewed as a replacement for collective redress before the courts, as administrative procedure should not be perceived as a sort of "general practice" procedure. Similar arguments purport the proposal to involve other public bodies, primarily existing regulatory agencies in protection of consumer's collective interest.
\end{abstract}

Key words: consumer protection, collective redress, collective interest, special administrative procedure, principles of administrative procedure, Ministry, inspection oversight. 